\title{
Non-Destructive Material Testing (Ndt) Techniques Applied for the Life Extension Program of the Aircraft in the Hungarian Defence Forces
}

\author{
BOZÓKI János ${ }^{1}$
}

\begin{abstract}
Most aircraft in the Hungarian Defence Forces (HDF) were planned back in the 1960s and 70s. Accordingly, strategies of operating and maintaining these aircraft reflect the level of engineering, technology and diagnostics of that era. However, since the mid 1990s until today a new generation of modern aircraft (JAS-39 EBS HU Gripen, MiG-29 tactical fighter aircraft) have been used in the Hungarian Defence Forces. By using these third and fourth generation fighters, new, modern operating and maintenance environment and systems have also been introduced. This publication is aimed at providing a short overview of Non-Destructive Ma-terial Testing; a very special segment of the many diagnostic testing methods used during life extension programs.

Keywords: Non Destructive Material Testing, life extension program, maintenance, tactical fighter aircraft
\end{abstract}

\section{Introduction}

In accordance with the recent changes in international security policies the Hungarian De- fence Forces are also going through dramatic and constant changes. That is, the Hungarian Defence Forces have changed profile from the 'good old" "mass" army to a modern, ever prepared force, ready to be deployed at once. In line with the above statement is a relatively new but widespread approach where not only the quality of deployment, but related opera- tional costs are equally important. Transport and combat helicopters in the HDF have either reached or exceeded their time limitations or are awaiting overhauls to extend their airwor- thiness in the following one or two decades. In addition no new (transport) aircraft have been procured or purchased since 2004. The end of airworthiness of these aircraft is due now. When manufactured these aircraft were planned to be in service up to 30 years and no longer. However, based on the present condition of these aircraft the manufacturer extended their life span another 10 years, coming to a total of 40 years now. Thus AN-26 transport aircraft will presumably be in service till 2015.

Currently the Hungarian Defence Forces have JAS-39 EBS HU Gripen fighter aircraft in service. These fourth generation aircraft and all their systems have been manufactured to meet the requirements demanded by "on-condition" operation. That is, all major parameters and performance of the aircraft are constantly monitored either by built-in or onboard instru- ments. Built-in warning and diagnostic systems and computer based ground support systems

1 Engineer colonel, Commander of HDF Aircraft Repair Plant, leju.pk@ mil.hu 
enable enhanced and increased efficiency operation. In case of operation, as for technical condition, classical preset life span cannot be defined as such thus this paper dos not deal with non-destructive material testing techniques used for this type of aircraft. After joining $\mathrm{NATO}^{2}$ in 1999 and due to the new requirements and as the result of strategic and defence inspections Hungary introduced changes in the fleet of combat aircraft in the Hungarian De- fence Forces between the years of 1998 and 2012 as shown in Table 1. [6]

Table 1. Number of aircraft in the Hungarian Defence Forces between 1998 and 2012. [6]

\begin{tabular}{|c|c|c|}
\hline Aircraft type & pieces as in 1998 & $\begin{array}{c}\text { pieces as } \\
\text { in February 2012 }\end{array}$ \\
\hline MiG-29B & 22 & 0 \\
\hline MiG-21BiSz & 12 & 0 \\
\hline MiG-29UB & 6 & 0 \\
\hline MiG-21UM & 10 & 14 \\
\hline JAS-39 GRIPEN & 0 & 5 \\
\hline An-26 & 4 & 0 \\
\hline Z-43 & 4 & 0 \\
\hline L-39ZO & 19 & 8 \\
\hline JAK-52 & 12 & 12 \\
\hline Mi-24V, D, P & 32 & 0 \\
\hline Mi-17P & 2 & 7 \\
\hline Mi-17 & 5 & 10 \\
\hline Mi-8 & 35 & 0 \\
\hline Mi-2 & 20 & 0 \\
\hline Mi-9 & 1 & $\mathbf{5 6}$ \\
\hline Total & $\mathbf{1 7 6}$ & \\
\hline & & 0 \\
\hline & 32 & 0 \\
\hline
\end{tabular}

In the following chapters non-destructive material testing techniques used during life extension programs of the previous aircraft types will be introduced.

\section{Airframe Damages}

\subsection{Surface, material flaws occurring during "Normal" operation}

The manufacturer sets techniques of $\mathrm{NDT}^{3}$ (crash test, fatigue test etc.) to be followed as part of other diagnostics. This information is available for the maintenance staff in the aircraft's service manual.

2 NATO - North Atlantic Treaty Organization

3 Non Destructive Testing 


\subsection{Surface, material flaws occurring during "Extreme" operation}

An aircraft may be deployed in extreme conditions several times during its life time. Aircraft manufacturers provide for end users the necessary procedures for these conditions which maintenance specialists may obtain during special courses. However extreme conditions cer- tainly do not merely root from extreme or higher than normal climatic or weather related issues but include any more severe than normal operating circumstances. These may be as follows:

- flaws caused by short interval but severe events (such as momentary overload, foreign object, projectile impact etc.)

- flaws caused by long interval impacts (such as material fatigue, corrosion etc.)

\subsubsection{Surface, material flaws caused by short interval impacts}

During short and intense events the aircraft is affected by extreme impacts leading to sudden and severe damage. In case of a projectile impact in metal structures "exit effect" — when the type of damage on the leading in and exiting sides is different and can be well separated

— is clearly visible. (See Picture 1 and 2) This feature of metal structures and components, detailed above, determines the technique of repair and testing to define the damaged area on the aircraft.

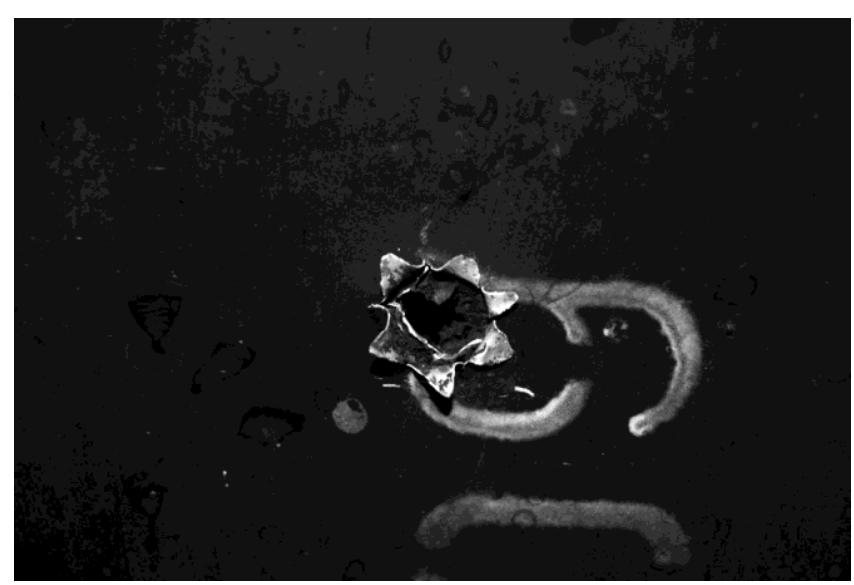

Picture 1. "Exit" effect after projectile impact [7] 


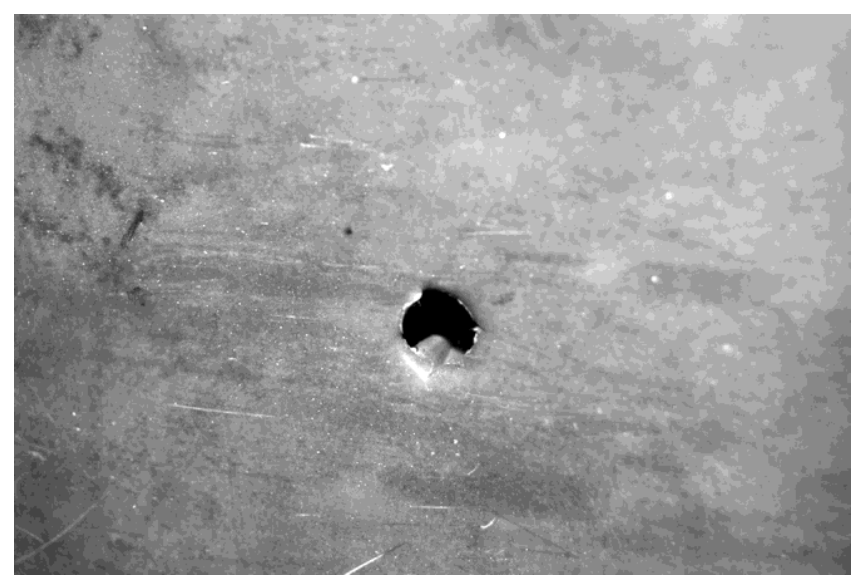

Picture 2. Entry damage after projectile impact [7]

Composite components due to their structural design and mechanical characteristics have a completely different response to loads. The diameter of a projectile impact to a composite component coincides with the cross-sectional diameter and the shape of the bullet itself. In one word there is no "exit" effect when composite components are hit. (Picture 3) The place of the impact regardless of its size may influence the aircraft's airworthiness (in case an attachment gets hit, the aircraft has to delete its sortie). Energy affecting composite structures of an aircraft get transferred by fibres and absorbed by the matrix material. In case of impact, layers made up from fibres get segregated from one another and in extreme conditions may get broken apart, thus causing damage or flaws in the composite material. (Figure 2) Gen- erally, it is not that easy to classify damage types because delamination and fibre abruption may occur at the same time. But in many cases it is more typical to find broken layers and delamination around and in the vicinity of affected areas. We may find areas of damage as shown in Picture 4.

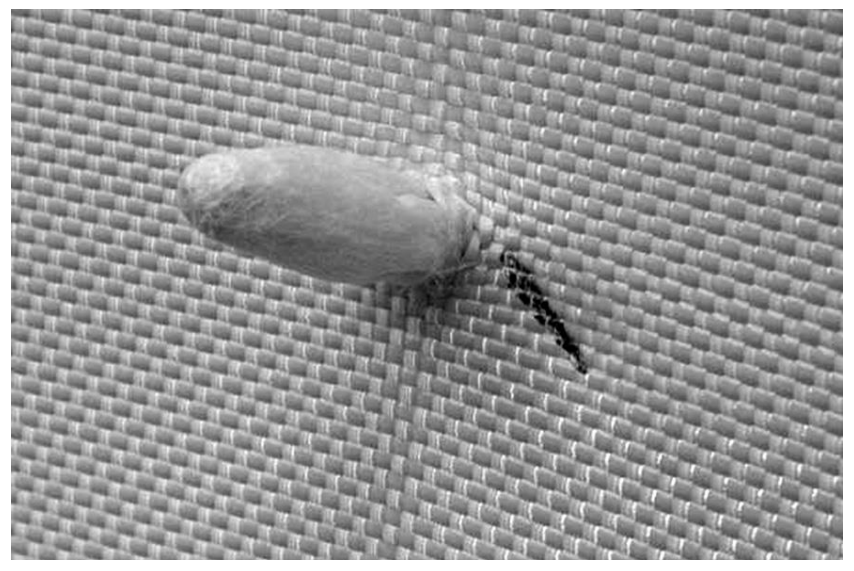

Picture 3. Fibre abruption upon impact [4] 

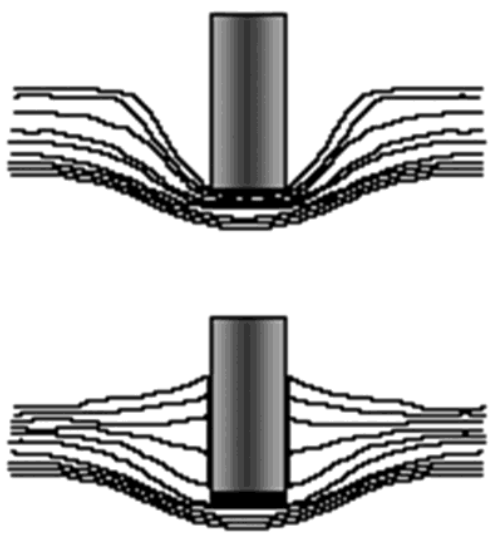

Figure 1. Projectile penetration through woven material [4]

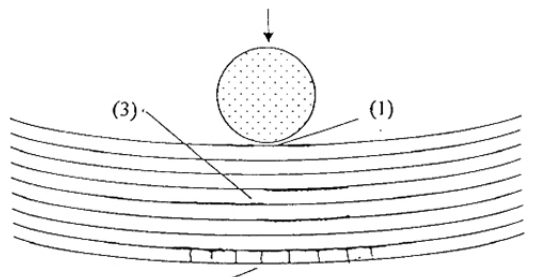

(2)

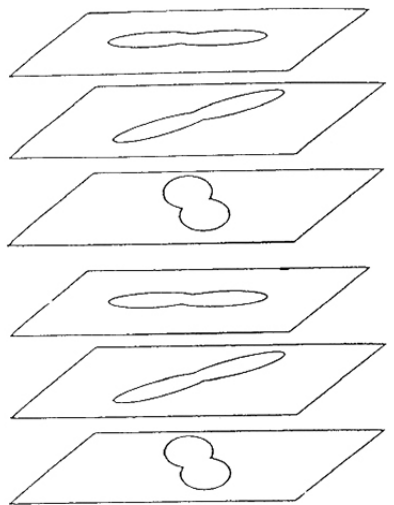

Figure 2. Layer delamination due to foreign material impact [2] (Legend for Figure 2.4)

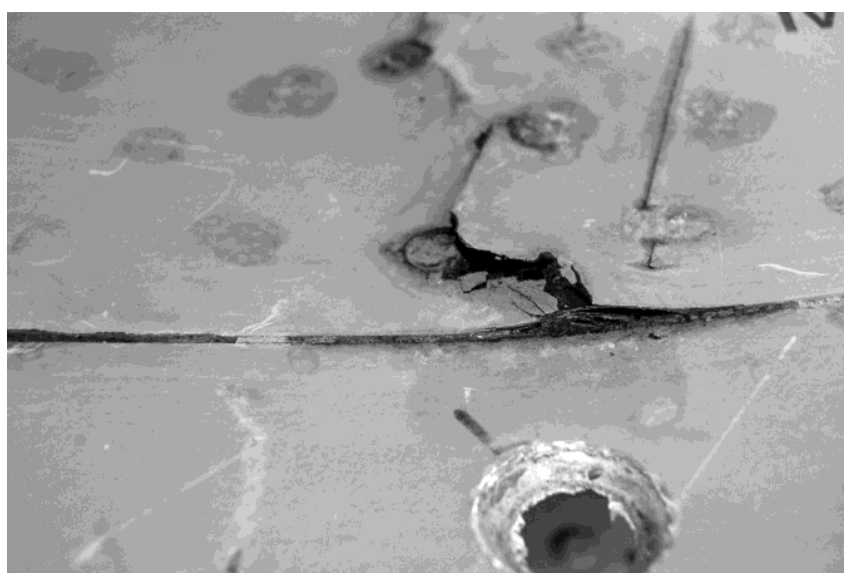

Picture 4. Damage to composite structures [7]

4 1-indent; 2 - fault caused by drag; 3 - delamination in adjacent layers due to shearing forces 


\subsubsection{Surface, flaws caused by long interval impacts}

Airframe life span is mainly determined by the amount of random damage and wear due to short interval loads and corrosion. Maintenance and operational handbooks aim to reach maximum life span. However engineers take several extreme operating and maintenance factors into consideration while designing an aircraft. Unfavorable operating and storing fac- tors and their disadvantageous effects are to be considered as higher than normal or planned aircraft usage. Open air storage in unfavorable weather or climatic conditions may cause the aircraft airframe to suffer corrosion. [5] It is almost inevitable for metal structures to be in physical contact with composite components conducting electric currents and causing severe corrosion to metal parts, components and structures. This kind of corrosion is called Galvan corrosion or contact corrosion.

\section{Contact Corrosion}

Metal surface contact corrosion is a process of deterioration starting off from the surface of a metal surface based on oxidation. This process requires the presence of another conductor with higher positive potential than the previous material. Galvanic corrosion takes place on the anode of an electrochemical corrosion cell (a corrosion cell and a local cell) in case of the presence of certain electrolytes. The rank of metal voltage ranges from Cesium with the highest negative charge until the element with the highest positive charge. Table 2 illustrates the list of materials by their potential used for aircraft manufacturing. [1]

Table 2. Materials used in aircraft manufacturing [1]

\begin{tabular}{|c|}
\hline ANODE \\
\hline Magnesium Alloys \\
\hline Aluminum Alloys \\
\hline Aluminum \\
\hline Cadmium \\
\hline Steel and Iron \\
\hline Brass, Copper and Bronze Alloys \\
\hline Stainless and heat resisting steel \\
\hline Titan \\
\hline Nickel and Nickel Alloys \\
\hline Graphite composites \\
\hline CATHODE \\
\hline
\end{tabular}

Electrically conductive graphite fibres contacting metal will cause the metal part to cor- rode hard. The main reason is the significant potential difference of graphite, aluminum and cadmic steel. In the vicinity of composite component contacting metal structures, metal structures lose strength and wear down. [1] 
Therefore contact corrosion can be prevented with selecting the right material and using proper insulation. For the same reason only corrosion-proof bonding units — made from materials like corrosion-proof Titan and stainless steel — can be used for graphite woven material.[2]

Picture 5 illustrates carbon fibre composite and aluminum made structures.

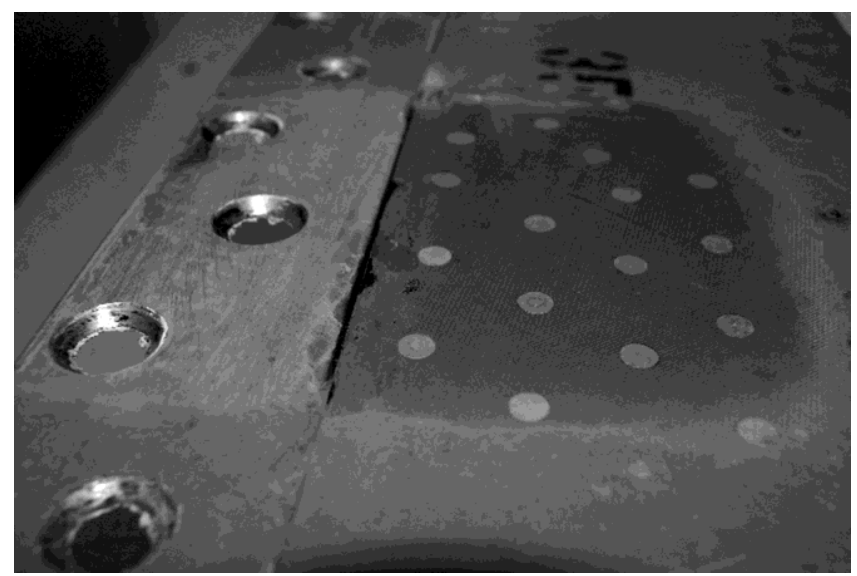

Picture 5. Carbon fibre composite and aluminum made structures [7]

\section{Non-Destructive (Material) Testing}

The operative management and effective planning of aircraft life extension works are impos- sible without up-to-date diagnostic systems. One special element of this diagnostic system is Non-Destructive Material Testing.

Below is a list of main non-destructive material testing methods, mainly the ones used for aircraft life extension programs:

- Visual Test (VT);

- Magnetic Particle Test (MT);

- Liquid Penetration Test (PT);

- Ultrasonic Test (UT);

- Eddy Current Test (ET);

- X-ray Test (RT).

The wide range of repairs and the limitation of each testing method require the usage of multiple testing methods. There are loads of testing methods with different efficiency to de- tect failures. Their applicability greatly depends on the characteristics such as the size of the object, the time available for the test and environmental conditions. Therefore comparing the result of each testing method will not provide an exact answer. The first step to take before performing a test is to clarify the task and to choose the most suitable testing method or a set of different methods that fit the task. Non used destructive testing methods used largely depend on the type, size, direction, position, depth of damages to be detected in aircraft parts. 


\subsection{Visual Testing}

This kind of testing is mainly used for detecting mechanical wear, surface corrosion and damages, chip-offs, tears, permanent deformations, plating material damages, deposits, con- tamination and leakages. To observe and test elements and parts of an aircraft not accessible to the naked eye (combustion chamber turbine etc.) endoscopes are used.

Picture 6 illustrates an image taken for determining the size of damage to a turbine blade with an endoscope.

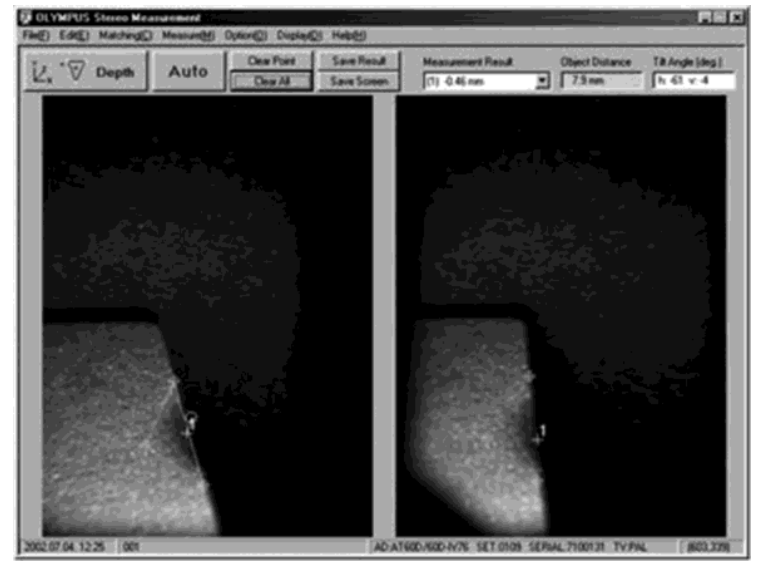

Picture 6. An endoscopic image [7]

\subsection{Magnetic Particle Test}

Magnetic particle material testing is used to detect flaws in near surface regions in ferromag- netic parts of an aircraft. [11] The main point of this testing is that the testing material (mag- netic particles) accumulates over the damaged surface revealing the magnetic field and thus the flaws. This testing method is very sensitive and reliable. With this method it is relatively easy to detect the location and the size of the damage. However there are some drawbacks to this testing method:

- thicker protective layers must be removed before testing;

- magnetic particles may get into joints and fill them up;

- special attention must be paid to demagnetize parts around joints.

However, magnetizable powders are more sensitive thus giving higher reliability in de- tecting flaws than other dry powders. At the same time fluorescent magnetic testing materials have higher sensitivity than color contrast ones. In a case where background light cannot be dimmed properly, higher accuracy testing results can be gained using a balancing contrast agent along with colored testing agent. [12] Test output sensitivity in certain environmental circumstances can be established using test samples (standards) as seen in Picture 8 and 9. Picture 7 shows a crack on an annular gear detected with non-destructive testing. 
BOZÓKI János: Non-Destructive Material Testing (Ndt) Techniques Applied for the Life Extension Program...

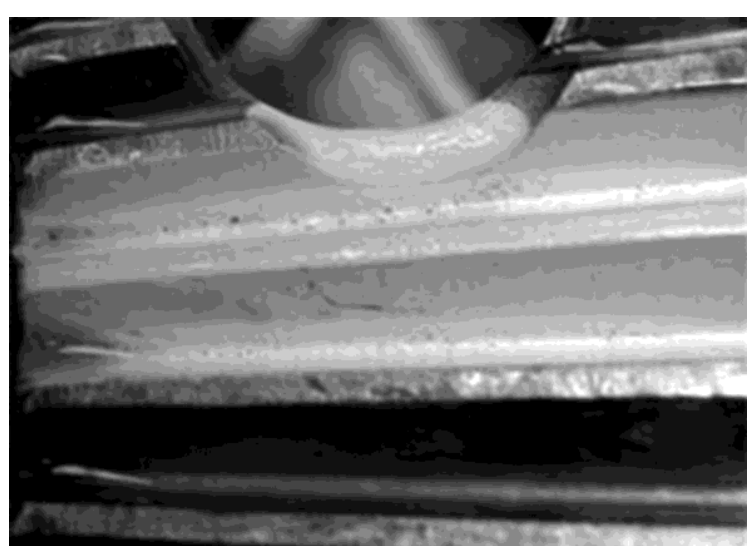

Picture 7. Crack NDT detected on an annular gear [7]

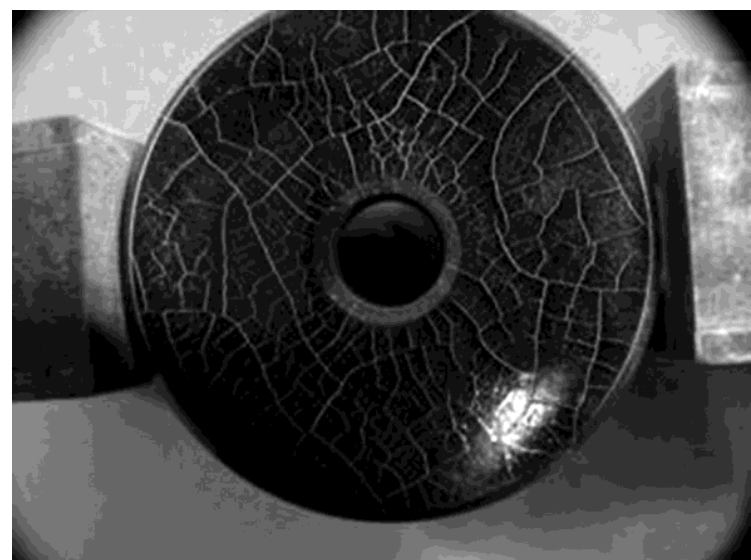

Picture 8. Testing standards to set magnetic particle testing sensitivity [7]

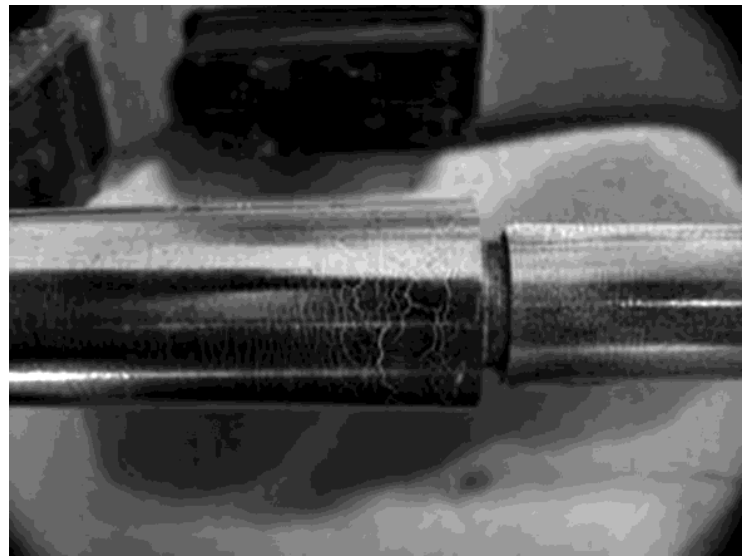

Picture 9. Testing standards to set magnetic particle testing sensitivity [7] 


\subsection{Liquid Penetration Test}

Liquid penetration tests are used to detect flaws open for liquid to enter. [9] Liquid pene- tration tests enable testing the whole of the surface of irregular shaped objects at the same time. This test comes with high resolution and sensitivity and detects the size and location of possible flaws.

Disadvantages:

- Contamination and protective layer(s) are to be removed before testing. Preparing the surface for the test is a time consuming task. For instance, during the test of a magne- sium component it is vital to take care of corrosion protection, which is almost impos- sible on the battlefield.

- The testing takes between 2-4 hours so it is rather lengthy. Below freezing point the possibility of false test results gets higher (due to condensation and the resulting liq- uid — mainly water — fills up flaws and cracks preventing testing liquid penetration.

- Does not tolerate inaccurate testing and is sensitive to environmental conditions (il- lumination, temperature). Picture 12 - a crack on an annular gear detected liquid penetration test.

The sensitivity level of testing agents can be established using test samples [10] where the resulting reading is compared with the standard/sample photo. Using this technique we can get information on the level of sensitivity in different conditions as seen in Picture 10 and 11.

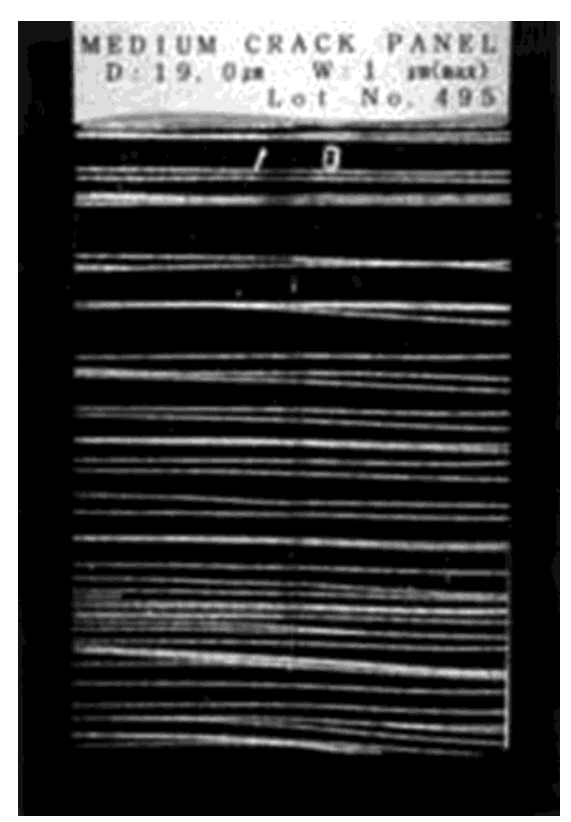

Picture 10. Test sample number 2 [7] 
BOZÓKI János: Non-Destructive Material Testing (Ndt) Techniques Applied for the Life Extension Program...

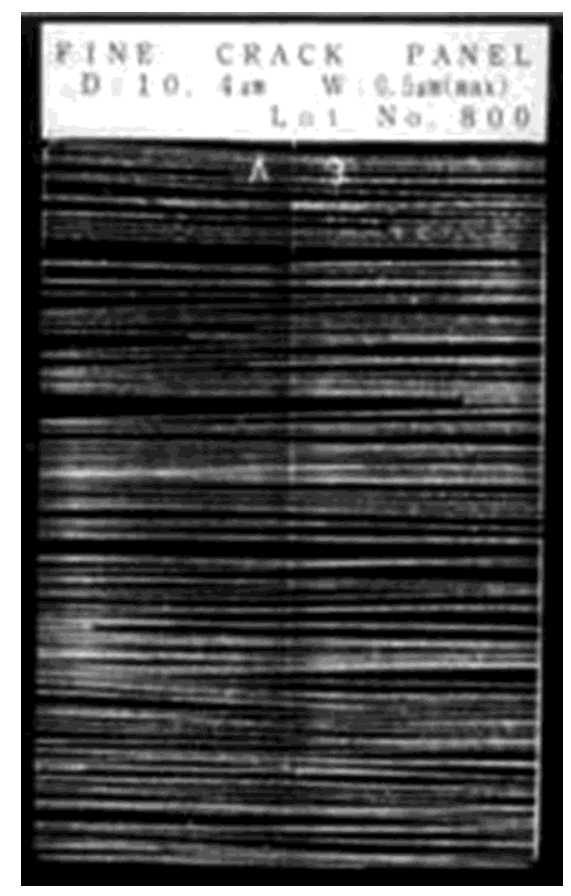

Picture 11. Test sample number 3 [7]

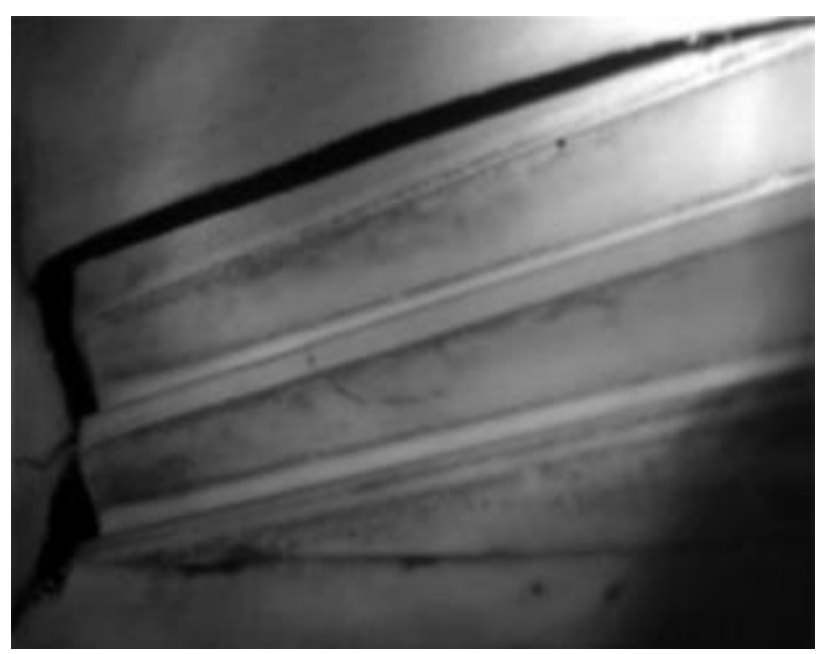

Picture 12. Crack on an annular gear detected liquid penetration test [7] 


\subsection{Eddy Current Test}

Eddy current tests are used to detect flaws on and under the surface. The principle of the test is as follows: eddy current in a tested material is compared with another eddy current of a sample. [13]

This is a fast testing method because the layer covering an aircraft component does not need to be removed beforehand.

However, this method has disadvantages too. See below:

- Sensitivity, thus test data are largely affected by the fact that a probe (optimized for a single test needs to be used. Depending on the size and shape of the object to be tested different probes need to be used;

- Testing large areas is demanding;

- Special attention must be paid when testing magnetizable components since heteroge- neity of the tested material affects test results;

- In case of eddy current tests of ferromagnetic materials, fault signals are hard to sep- arate from the local fluctuation of permeability. However, magnetic saturation of the tested material, and as a result effective permeability drops to 1.0 , is a solution to the above problem.[8]

Eddy current testing is an indirect method though. Calibration standards/samples need to be used to determine the size of the flaw due to the difference of size and chemical composi- tion of the tested material and the variable parameters of the numerous search coils plus the sensitivity depending on the testing frequency.

Testing samples/standards as seen in Picture 14 help determine flaw size of different materials.

Picture 15 shows probes used for testing different materials. Picture 13 reveals cracks under painted areas caused by overloads.

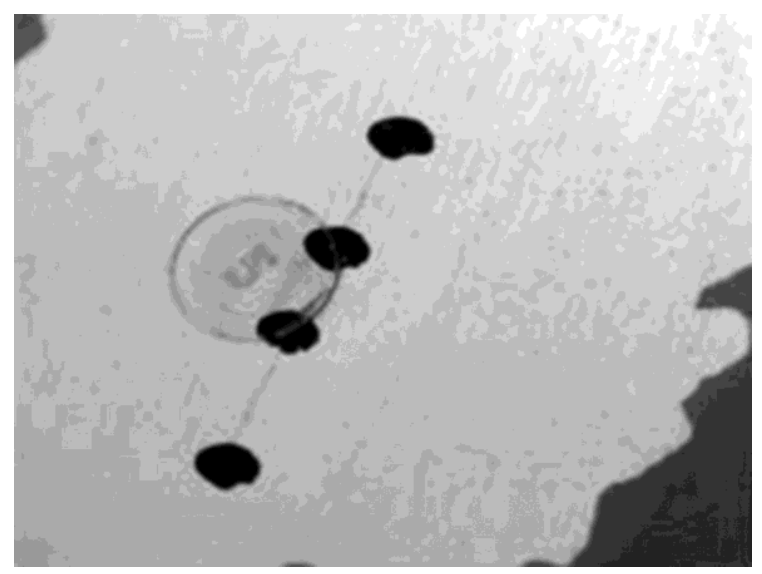

Picture 13. Cracks between rivets [7] 


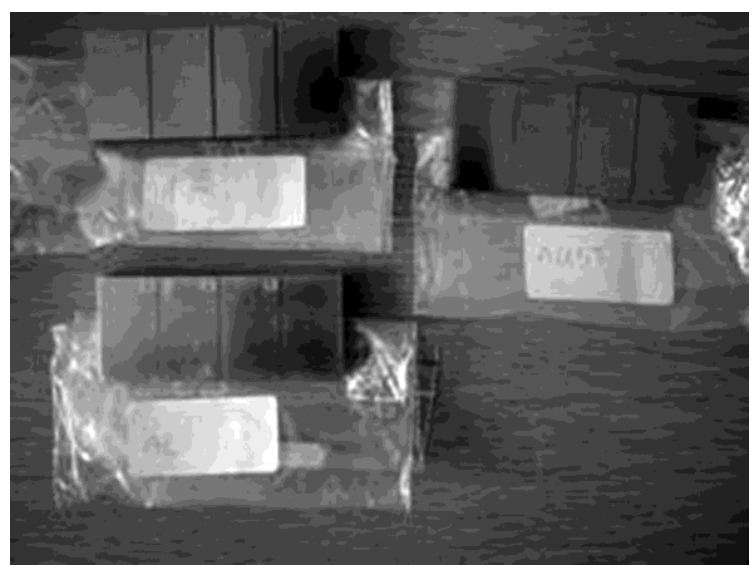

Picture 14. Testing samples/standards to determine flaw size of different materials [7]

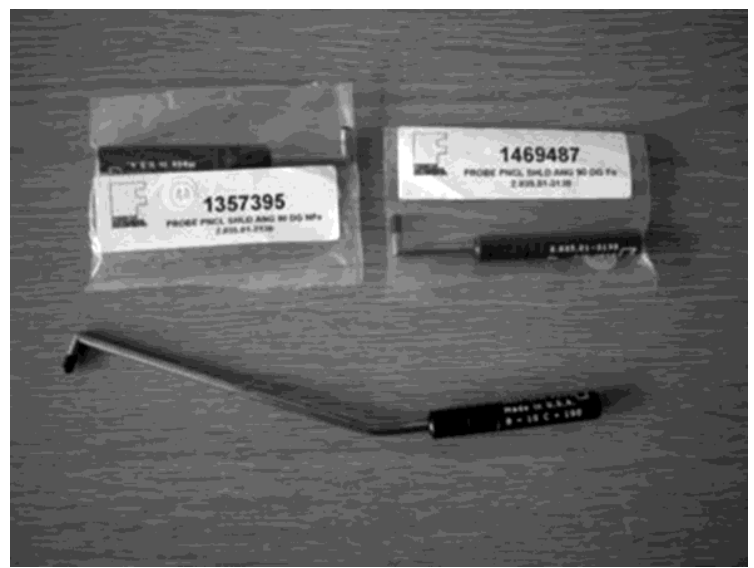

Picture 15. Probes to test different materials [7]

\subsection{X-ray Test}

Even in normal operating conditions using X-ray testing requires major infrastructure and safety investments. X-ray testing is more effective and necessary than rewarding. Testing machinery, designing and manufacturing companies pay great attention to provide the high- est level of reliability using the fewest possible resources. Components for aircraft sub- and main systems are manufactured to meet strict quality assurance principles. Based on my pre- vious experience I would say during a normal aircraft life extension program it is not typical to perform X-ray testing as a means of nondestructive testing. 


\subsection{Ultrasonic Test}

The principle of ultrasonic testing is to transmit high frequency audio impulses into the com- ponent to be tested and the back echoed signals reveal flaws inside (under the surface of) the material. [14] This testing provides high level accuracy to detect flaws on the surface and under the surface defects. Probes and testing standards are a must for successful ultrasonic testing.

Picture 16 shows probes used for ultrasonic tests.

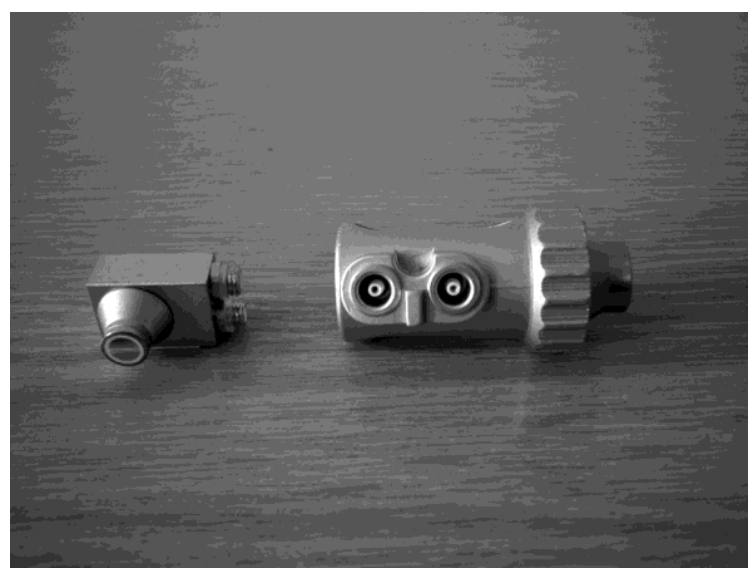

Picture 16. Ultrasonic test probes [7]

To perform ultrasonic testing the right thickness is to be selected on the testing standard as per the geometrical parameters of the aircraft structure to be tested.

Geometrical and sensitivity parameters of the probe are set by using a testing sample as seen in Picture 17.

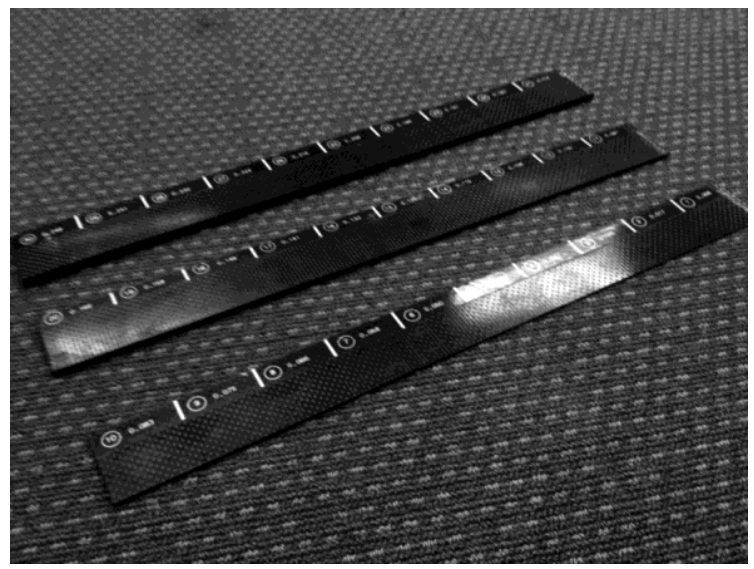

Picture 17. Composite test samples [7] 
As soon as the right calibrations are completed the testing is rather fast and accurate. Test data are displayed and stored (for further reference) on the testing equipment.

Picture 18 shows back echo signal on the display of USM-25 ultrasonic testing equipment.

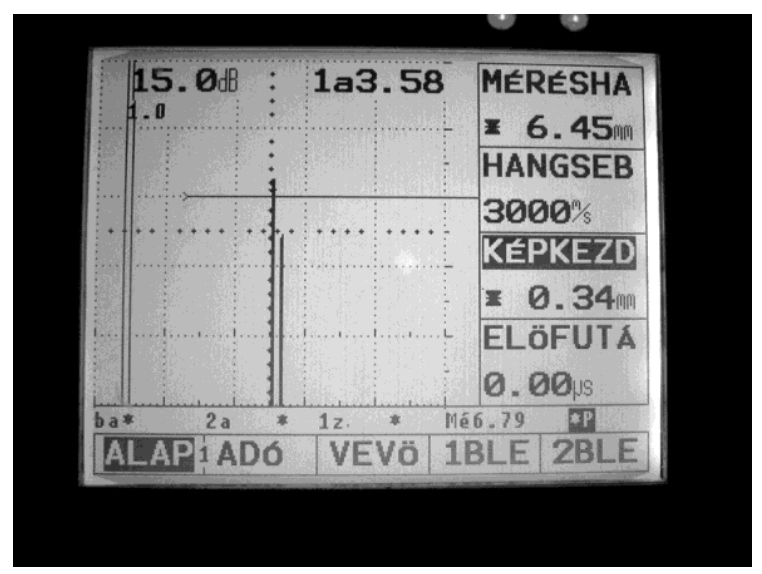

Picture 18. USM-25 ultrasonic testing equipment [7]

\subsubsection{Ultrasonic testing of fibrous composite structures}

To avoid inaccurate test results a technology is to be developed before testing accidental failures and complex components. Un- and remounting a component to be tested from an air- craft takes a long time but a carefully prepared testing method can save lots of precious time.

To detect, locate and verify repaired damage caused by foreign objects or projectile im- pacts (alternately broken and delaminated layers) there are a variety of testing methods with different feasibility and efficiency levels.

Figure 3 - composite component delamination detection chart. Figure 4 - composite component fracture detection chart.
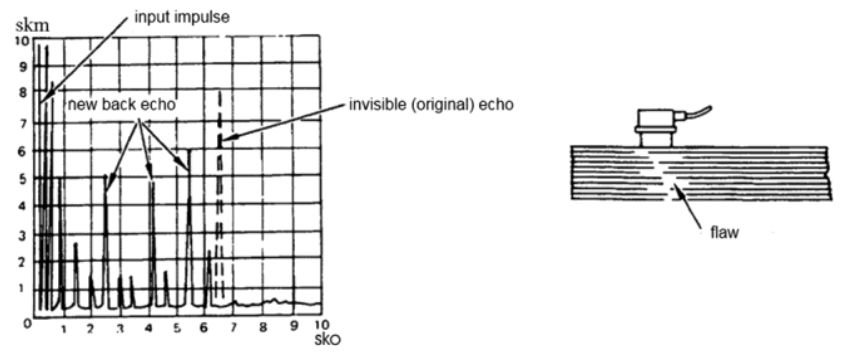

Figure 3. Fracture detection chart [2] (Legend for Figure $3^{5}$ )

5 skm — scale height, sko — scale 

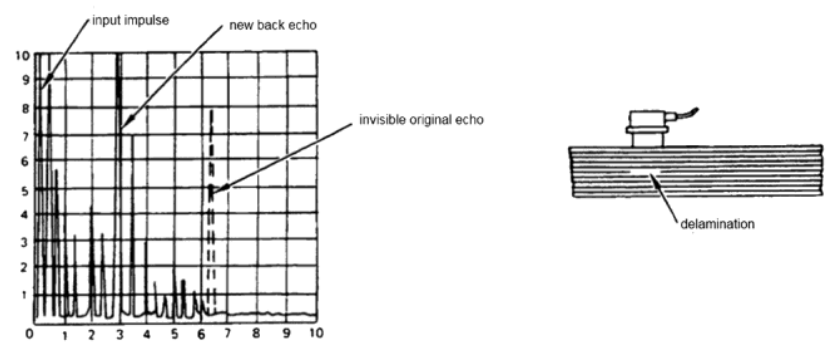

Figure 4. Delamination detection chart [2]

Based on my previous experience and benchmark technical literature ultrasonic testing methods are highly suitable to detect flaws resulting from short and long time impact to an aircraft structure.

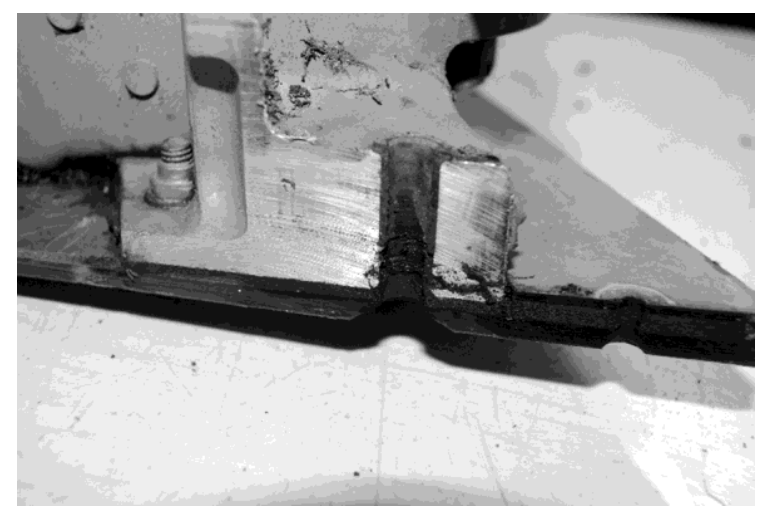

Picture 19. Aluminum and carbon fibre assembly [7]

Picture 19 illustrates contact corrosion at the assembly point of aluminum and carbon fibre structures. This kind of flaw of a composite structure cannot be detected with ultrasonic testing. The only suitable solution here is to ultrasonic test the aluminum component. A test like this can be performed with the technologies and equipment available in the Hungarian Defence Forces.

\section{Summary}

In my paper I wished to introduce non-destructive testing methods used for aircraft life extension programs. Certainly it is a really hard and challenging professional job to provide technical support to any equipment used in the Hungarian Defence Forces. Maintaining and operating aircraft in the Hungarian Defence Forces requires the presence of specialists whom on a daily basis face the challenges posed by new technologies, systems and materials. De- veloping new technologies and training specialists to match the given tasks are inevitable to provide constant, professional support to aircraft maintenance. The necessary certifications and licenses are ensured through special courses organized and authorized by the manufac- 
BOZÓKI János: Non-Destructive Material Testing (Ndt) Techniques Applied for the Life Extension Program...

turer. However, simply increasing the number of employees does not certainly mean they can match any situation. The key to success is to establish complex work teams with all the necessary knowledge, expertise and equipment.

\section{References}

[1] NIU, M. C. Y. (1992): Composite airframe structures. Granada Hills: Adaso Adastra Engineering Center, ISBN 9627128066 (p. 43., p. 380., p. 541.)

[2] Non-destructive test manual. Boeing Document, d6-37239 December 5 2003. (Part 1 p. 22. , Part 4 p. 8.)

[3] DAVIES, G. A. O., OLSSON, R.: Impact on composite structures, Department of Aeronautics. The Aeronautical Journal, 11 (2004), 541. DOI: https://doi.org/10.1017/S0001924000000385

[4] KOCER, H. B. (2007): Laminated and hybrid soft armor system for ballistic applications. Alabama: Auburn University

[5] BÉKÉSI B. (2006): A katonai repülőgépek üzemeltetésének, a kiszolgálás korszerüsitésének kérdései. (Questions Raised by The Modernization of Military Aircraft Operation and Servicing.) Budapest: Zrínyi Miklós Nemzetvédelmi Egyetem, Ph.D. dissertation

[6] POGÁCSÁS I. (2012): A repülőeszközök mérnök-müszaki biztositásának és üzemeltetésének vizsgálata a fegyverzetváltással összefüggésben. (An Investigation of Aircraft Engineering and Technical Support for Military Aircraft.) Budapest: Nemzeti Közszolgálati Egyetem, Ph.D. dissertation

[7] MH Légijármü Javitóüzem (Hungarian Defence Forces Aircraft Repair Plant)

[8] TÓTH F.: Roncsolásmentes anyagvizsgálatok. (Non-Destructive Testing Methods.) Anyagvizsgálók Lapja, 3 (1994)

[9] Annual Book of ASTM Standards Metals Test Methods and Analytical Procedures 2003: Liquid Penetrant Examination.

[10] Roncsolásmentes vizsgálat. Folyadékbehatolásos vizsgálat. (Non-Destructive Testing. Liquid Penetration Test.) MSZ EN ISO -3452-3:2000

[11] Annual Book of ASTM Standards Metals Test Methods and Analytical Procedures 2003: Magnetic Particle Examination.

[12] Mágnesezhetö poros vizsgálat. (Magnetic Particle Test.) MSZ EN 1290:2004

[13] Annual Book of ASTM Standards Metals Test Methods and Analytical Procedures 2003: Electromagnetic (Eddy-Current) Method.

[14] Military Standardization Handbook: Nondestructive Testing Methods of Composite Materials - Ultrasonic. MIL-HDBK-787 01041988 www.everyspec.com/MIL-HDBK/ MIL-HDBK-07000799/MIL_HDBK_787_1950/(downloaded: 1209 2012) 